\title{
THE TRAVELS OF CRITIQUES OF NEOLIBERALISM: URBAN EXPERIENCES FROM THE 'BORDERLANDS'
}

\author{
Idalina Baptista ${ }^{2}$ \\ Oxford Programme for the Future of Cities \\ Institute for Science, Innovation and Society \\ School of Anthropology and Museum Ethnography \\ University of Oxford
}

\begin{abstract}
This article contributes to the ongoing scrutiny of the travels of critiques of 'neoliberalism' in urban studies. Using the case of a state-led urban regeneration program implemented in Portugal since 2000, the Polis Program, the article weighs in on metaanalytical discussions about the hegemonic status of neoliberalism as a theoretical concept and as an analytical framework and on discussions about the travels of dominant critiques of neoliberalism beyond the sites of epistemological production. The article argues that the current analytical overinvestment in neoliberalism may obscure important drivers of contemporary urbanization and that recourse to a diversity of concepts may be a more profitable line of inquiry. The article suggests that current efforts at epistemological renewal within urban studies benefit from taking up cities in the 'borderlands' of urban theory as relevant cases in their own right. The article offers further considerations on the purchase of 'neoliberalism' in contemporary urban literature.
\end{abstract}

\section{INTRODUCTION}

Scholars have become increasingly interested in the way urban policy and planning ideas travel from city to city (Healey and Upton, 2010; Robinson, 2011; Roy and Ong, 2011; Healey, 2012). The tendency has been for scholars to critique such travels primarily as urban expressions of neoliberalism, theoretically explained either as a hegemonic political economic project that favors the logic of capitalist accumulation (Smith, 1996, 2002; Brenner and Theodore, 2002a; Peck and Tickell, 2002; Harvey, 2005) or as part of a widespread expansion and appropriation of neoliberal technologies of governing (Larner, 2003; Ong, 2006).

The travels of such critiques of neoliberalism are also undergoing scrutiny. With calls for an epistemological renewal in urban studies (Robinson, 2006; Roy, 2009), scholars are increasingly wary of the work that mainstream analytical frameworks of neoliberalism are asked to do when 'traveling' to sites other than their referents-i.e. to cities outside the 'heartlands' of the capitalist core or directly influenced by institutions in that core. For instance, some scholars have noted the inconsistent handling of neoliberalism as a theoretical concept and worry that many authors take its meaning for granted, while failing to dedicate detailed analytical attention to the fundamentally variegated nature of neoliberalization processes (e.g., Peck, 2004; Brenner et al. 2010). Other scholars share in these analytical concerns but highlight the limitations of dominant (Marxist) 'political economy' treatments of neoliberalism (Larner, 2003; Barnett, 2005; Barnett et al., 2008; Clarke 2008; Robinson, 2011). Many have suggested that a 'governmentality' approach to the study of neoliberalism may be more profitable (Ferguson and Gupta, 2002; Ong 2006), but a few other theoretical lenses are now rising to prominence and animating a diversity of research agendas on neoliberalism in urban studies (Bakker, 2005, 2010; Castree, 2008a, 2008b; Ferguson, 2009, 2011; Collier, 2011, 2012; Parnell and Robinson, 2012). 
More recently, some scholars have expanded their concerns beyond how to study neoliberalism (and neoliberalization) to questioning the seeming over-commitment to neoliberalism as an analytical framework in urban studies. Some scholars believe that a methodological commitment to neoliberalism as a hegemonic concept fails to explain diverse political formations and urban interventions (e.g., Collier, 2011, 2012) or to identify a wider diversity of drivers of urban change in cities outside the 'heartlands' of urban theory (e.g., Parnell and Robinson, 2012). Others argue that dominant treatments of neoliberalism limit the possibilities for envisioning more progressive forms of urban politics (e.g., Ferguson, 2009, 2011).

This article contributes to these meta-analytical discussions by addressing two particular concerns: the status and the sites of epistemological production of neoliberalism. For this purpose, the article examines the formation and local critiques of the Polis Program, a state-led urban rehabilitation and environmental improvement program implemented in Portugal since 2000. The article's contribution is two-fold. First, using the Portuguese case, the article offers empirical insights to weigh in on the meta-analytical discussion about an overinvestment in the hegemonic status of neoliberalism as a theoretical concept and as an analytical framework. ${ }^{3}$ The article makes the argument that examining the Polis Program by using neoliberalism as the primary analytical framework (whether with a 'political economy' or a 'governmentality' lens) provides useful but only partial insights into the drivers leading up to the program's formation. The article suggests the Polis Program draws inspiration from neoliberal ideas available in the EU policy arena, not with the purpose of intensifying market rule and commodification, but as a way of facilitating a welfare intervention in Portuguese cities. Alongside dominant interpretations of neoliberalism, concepts such as welfare state, democratization and modernization are equally helpful in understanding the formation of the Polis Program. As a result, the article suggest that instead of a methodological overcommitment to neoliberalism, a more profitable line of inquiry emerges if neoliberalism's hegemonic analytical status is brought on par with other explanatory concepts. Second, the article contributes to the ongoing scrutiny of the sites of epistemological production of neoliberalism by using a case from the 'borderlands' of Europe as an object of inquiry of contemporary urban policies. The article suggests that current efforts at epistemological renewal within urban studies would benefit from taking up these European cities as relevant cases in their own right because their urban condition is dissimilar (but not exceptional) to that reported in the 'heartlands' of urban theory (Baptista, 2012). This is because there is urgency in reflecting on cases that map uneasily onto the mainstream concepts and analytical lenses in urban theory (such as neoliberalism), if we are to take stock of the different ways in which urbanization and urban politics play out today in different parts of the world. Taking this Portuguese case study contributes to questioning further the degree to which the hegemony of 'neoliberalism' - as a conceptual and analytical referent - is taken for granted in the implicit comparative examinations of the urban condition we find today in urban studies (Nijman, 2007; Robinson, 2002, 2010; McFarlane, 2010; Ward, 2010; Jacobs, 2012; McFarlane and Robinson, 2012). In focusing on the moment of formation of the Polis Program, the article is thus less concerned with adjudicating the local effects of neoliberal ideas following the program's implementation, and more interested in engaging and contributing to ongoing meta-analytical debates regarding the study of contemporary urbanism.

The following section provides an overview of scholarly discussions of critiques of neoliberalism as a theoretical concept and as a dominant analytical lens in the study of contemporary urbanism, and how that approach may provide a very partial understanding of urban conditions in cities in the 'borderlands' of urban theory. The article proceeds with an investigation of how policymakers mobilized different neoliberal ideas into the formation of 
the Polis Program, while envisioning an expansion of the welfare state to address urban problems. The article then examines the critiques of the Polis Program advanced by politicians, academics-cum-critics, and opinion-makers. In doing so, the article highlights how discussions about the Polis Program reflected broader implicit concerns with the country's democratization and modernization towards an idealized 'European' state apparatus. The article concludes with a discussion of the insights provided by the Portuguese case regarding the use of neoliberalism as a theoretical concept and as an analytical framework in contemporary urban literature.

\section{TRAVELING CRITIQUES OF 'NEOLIBERALISM'}

Concerns over neoliberalism as a theoretical concept and as an analytical framework are not new. ${ }^{4}$ Nearly a decade ago, Peck $(2004$, p. 393) recognized how, "for all its analytical and political elasticity, neoliberalism [had] attained the status of a buzzword in critical human geography circles." Urban scholars within the critical tradition developed out of Marxism (e.g., Smith, 1996, 2002; Harvey, 2001, 2005; Brenner and Theodore, 2002a, 2002b) called for a detailed investigation of the various ways, sometimes conflicting and contradictory, in which market rule was being naturalized as a governing logic, driving processes of state restructuring in a commitment to an overall capitalist logic of accumulation. In their political economy approach, these scholars were especially attuned to the reworking of local institutional landscapes in places in the capitalist core (e.g., United States and United Kingdom) or directly influenced by institutions in the core (e.g., Latin America), as well as to the many contestations of neoliberalization (e.g., Leitner et al. 2007; Brenner et al., 2012). The structuralist perspective, emphasizing the different modes of neoliberalization in diverse contexts, has produced a prolific and engaging stream of work over time (e.g., Brenner and Theodore, 2002b; Jones and Ward, 2002; Brenner, 2004; Mitchell, 2004; Boudreau et al., 2009; Peck et al., 2009). For that reason, it has been recognized as the dominant critique of neoliberalism (e.g., Ferguson 2009; Collier, 2011; Parnell and Robinson 2012).

Process of urbanization have been an apt field for the study of neoliberalism, especially in recognition of what Harvey (2001) called the 'spatial fix' for the crises of capitalism. In spite of a lack of agreement regarding particulars, scholars have pointed out how neoliberal reforms and ideologies have driven urban entrepreneurialism and interurban competition to the core of urban governance, in an attempt to attract investment capital to cities (Harvey, 1989; Weber, 2002). Even though the material expressions of these processes are varied, many scholars have noted the use of similar urban strategies (e.g., large-scale urban redevelopment projects, signature mega-events, and place marketing) and governance tools (e.g., elite coalitions, public-private partnerships, practices of exception) across cities of the capitalist core (Swyngedouw et al., 2002; Moulaert et al., 2003). Investigations of urban neoliberalism along these analytical lines often tease out the ways in which cities become sites of growing inequality and social polarization, when the logic of capitalist accumulation seemingly drives urban transformation (cf. Smith, 1996).

Whilst this line of inquiry has been cardinal in providing an understanding of processes of neoliberalization and in scrutinizing its (mostly negative) effects the world over, its focus on macro-structures has raised analytical concerns. Experimentation with other theoretical lenses brought analytical diversity to this vibrant field of inquiry, especially through the work of scholars adopting a poststructuralist perspective and sharing a commitment to an ethnographic approach that privileges local understandings over metatheoretical analyses (e.g., Ferguson and Gupta, 2002; Larner, 2003; Ong, 2006). Deploying Foucault's notion of 'governmentality', these scholars focused on the micro-dynamics of 
neoliberalization processes, on how market rule was operationalized in everyday routines to variously (re)constitute the state, space, and subjects, as well as to accommodate diverse rationalities of government (Dean, 1999; Miller and Rose, 2008). Seeing value in both the 'political economy' and the 'governmentality' approaches, ${ }^{5}$ it has been suggested that both analytical frameworks can help in understanding the "complexity and contradictions of the processes associated with contemporary forms of rule" (Larner, 2003, p. 511). Yet, this call for analytical reconciliation is seen as problematic by those who believe the study of neoliberalism through the lens of 'governmentality' tends to value contingency and contextuality over the interconnections and commonalities across market-driven regulatory projects (Brenner et al., 2010). Others advise against a compromise between the two approaches due to their irreconcilable theoretical, analytical and normative differences (Barnett, 2005; Barnett et al., 2008). Others still suggest that adopting analytical lenses that denounce the ills of neoliberalism at the intersection of hegemony, surveillance, and oppression yields little possibility for a reparative reading of the present, as Sedgwick (2003) once put it, and for conceiving progressive forms of politics (e.g., Ferguson, 2009, 2011).

My aim here is not to decide which of these two analytical lenses-'political economy' or 'governmentality' - is more profitable in the study of neoliberalism in urban studies, nor to weigh in on the debate regarding their potential reconciliation, however important those intellectual projects may be. These vibrant discussions on how we investigate neoliberalism in regard to contemporary urbanization are a sign of a field of inquiry that remains open to intellectual exchange and scrutiny and, hence, open to evolution and refinement. My interest here lies with ongoing discussions about the extent to which focusing on 'neoliberalism' per se is a helpful conceptual and analytical approach to theorize contemporary urbanization and urban politics in cities that have remained outside of the 'heartlands' of urban theory (cf. Robinson, 2006). Hence, I use this overview of critiques of critiques of 'neoliberalism' to foreground two pressing meta-analytic concerns: the status and the sites of epistemological production of 'neoliberalism' as a theoretical concept and as an analytical framework.

Some scholars have suggested that neoliberalism may perform better as an analytical framework if its hegemonic status is brought on par with other explanatory concepts (see below Collier 2011, 2012; see also Parnell and Robinson, 2012). For instance, Collier (2012, p. 194) brings into question the extent to which focusing analytically on uncovering diverse strategies of hybridization and variegation through which neoliberalism is locally appropriated can capture what is going on in different places. Collier's uneasiness comes from his study of political formations in post-Soviet Russia that do not map easily onto "the critical conventional wisdom" about neoliberalism (Collier, 2011, p. 8-9). Collier associates this conventional wisdom with authors writing along the lines of the 'political economy' approach and, inspired by the work of Foucault and by his commitment to an ethnographic approach, takes issue with the macro-structural use of neoliberalism as a "big Leviathan" (Collier, 2012). The author worries this analytical choice takes neoliberalism as a premise (something presumed to exist in advance) instead of an object of inquiry (something to be characterized, analyzed, and explained) (Collier, 2011). He proposes that we may gain more analytically if we were to retain recourse to neoliberalism as a concept "as though it were the same size as other things" (Collier, 2012, p. 186). Parnell and Robinson (2012, p. 597) advance a similar argument for widening the pool of concepts from which to develop an understanding of "the complex forces that structure contemporary cities." Placing their attention on urban poverty in South African cities, Parnell and Robinson (2012) open up for scrutiny the extent to which neoliberalism may be one amongst other useful concepts in understanding the dynamics of urbanization and local politics. In fact, following Robinson (2011), taking this analytical stance may help explain why governments adopt policies that 
look neoliberal but whose outcomes do not match the explanations provided by dominant scholarly critiques of neoliberalism. Following along similar lines, Ferguson $(2009,2011)$ provocatively invited scholars to consider the potential "uses of neoliberalism" in reinventing 'progressive' arts of government. Ferguson's argument is one of 'status' and of 'qualification' of neoliberalism. He reminds us that the constant invocation of neoliberalism and the focus on its negative effects in recent literature may do more to close than to open possibilities for investigating and addressing the challenges of contemporary urbanization. The stake for urban studies here seems to rest on two aspects. On the one hand, there is a theoretical issue regarding how best to account for the complex ways in which contemporary urbanization happens in different places. On the other hand, there is an analytical issue regarding whether the more profitable analytical starting point remains in the current overinvestment in a single overarching concept or on a diversity of equally relevant concepts.

These authors' interrogations signal a valuable precautionary attention to the tendency to essentialize some concepts as they 'travel' to perform analyses of contemporary urbanization away from their sites of epistemological production. Starting off from an admittedly 'Southern' position, Parnell and Robinson (2012) recognize the contributions made by dominant (political economy) critiques of neoliberalism in pointing to capitalist accumulation as a driver of contemporary urbanization and urban politics. They are, however, apprehensive about how this dominant perspective has taken on the status of a "ready-made interpretive framework" (ibidem, p. 594). They posit that urban theory has been distorted by the "prioritizing of ideas that speak to cities forged by the industrial revolution" and "the realities of the Anglophone parts of the world" (ibidem, p. 596; see also Robinson, 2006, 2011). More importantly, Parnell and Robinson believe that accepting this view of processes of neoliberalization can obscure, instead of making visible, the "multiple drivers of urban change" in cities of the South (ibidem, p. 597).

This move to displace and de-center the dominant sites of production of urban theory away from its Euro-American origins has significantly opened the way for the recognition that African, Asian, and Latin American cities have a contribution to make to the ongoing project of epistemological renewal in urban studies (Robinson, 2006; Roy, 2009; Watson, 2009). Yet, in singling out a 'universal' Euro-American city, this move overlooks what I have called elsewhere the persistently silenced and heterogeneous urban experiences that populate the landscape of the European continent (Baptista, 2012). ${ }^{6}$ Referring to the case of Portugal, I argued that this silencing has contributed to a continued scholarly understanding of the country's urban experience as not quite yet modern and the foreclosure of alternative urban futures beyond the (mostly Anglophone) Euro-American model (ibidem). Sandercock (1995, p. 77) once mentioned that she wanted to bring to planning theory "the voices from the borderlands," that is, the voices of a group of authors whom, she suspected, "many planning theorists [had] never read or, if they [had] read them, [didn't] think of them as colleagues in the theorizing enterprise." Sandercock's remark turns the spotlight to the role scholarship plays in making some places more visible than others, irrespective of what can be learned anew from each locale. Paying attention to the European urban experiences continuously conflated in the Anglophone Euro-American model, such as that of Portugal addressed in this article, is less about enabling a 'view from the South' of the European continent or staking a claim for a particularly 'Southern European' urban condition outside of the 'Northern European' 'heartlands'. Paraphrasing Sandercock (1995), taking, for example, the Portuguese urban experience into account allows for the voices from the 'borderlands' of Europe to be heard in their own right - as places with a contribution to make in the reconceptualization of contemporary urbanization, not just as receivers of conceptual models from elsewhere.

This article uses the Portuguese case of the Polis Program to take up and expand on these meta-analytical considerations. As discussed below, the strategy of admitting different 
theoretical concepts may prove more helpful in understanding the Polis Program than attempting to explain it primarily with recourse to neoliberalism. This is due in part to the fact that the Portuguese urban condition is dissimilar, while not exceptional, to cities forged by the industrial revolution, to use Parnell and Robinson's earlier expression. Many cities targeted by the Polis Program did not industrialize at the same time or in the same way as cities in the U.K. (cf. Salgueiro, 1992). This is not to say that Portuguese cities should be seen as 'lagging behind' other European cities. Instead, we should acknowledge that the challenges these cities faced in the early 2000s were unlike those of its European counterparts, even though the country was fully inserted in the open European market and the global economy (cf. Marques, 2004). Nor is this to deny that the logic of capitalist accumulation played a part in Portuguese urbanization in the $20^{\text {th }}$-century. Yet, as studies by scholars of Portuguese urbanization illustrate (cf. Cardoso, 1988; Silva, 1994; Portas et al. 2003), a political economy reading alone fails to provide a satisfactory account of the mechanisms driving the country's urban transformation. As a consequence, urban development programs, such as the Polis Program, which are reflective of these different conditions, take a form that cannot primarily be characterized in terms of neoliberalism, especially in its 'political economy' variant. If we are to take stock of the different ways in which urbanization and urban politics play out today in different parts of the world, we need to reflect on cases like the Polis Program which seemingly map uneasily onto mainstream models of urban theory.

\section{THE POLIS PROGRAM: 'NEOLIBERAL’ URBANISM IN SOUTHERN EUROPE?}

Nowadays, many countries have a landmark urban regeneration initiative upon which rests the hope of integrating the nation, a region, or a city in the global economy. In Portugal, one such case is the Polis Program, a state-led urban rehabilitation and environmental improvement program that started in 2000. In examining the formation of the Polis Program, this section proceeds in two parts. It begins with an overview of how policymakers framed the purposes of the Program at the intersection of contemporary EU urban policy and the specificities of the Portuguese context. ${ }^{7}$ The second part of the section examines critiques of the program in its early years (2000-2003). In particular, it focuses on the political debate held in the Portuguese Parliament leading up to the Program's approval, as well as on opinion pieces penned by academics-cum-critics and opinion-makers. The section highlights how the Polis Program emerged in a policy space in which political, technical, and academic elites conceived the state apparatus as instrumental in modernizing the country towards a welfare ideal, in spite of the dwindling purchase of this ideal in other EU countries.

\section{CRAFTING A ‘WELFARIST’ EURO-PORTUGUESE URBAN POLICY}

By the 1990s, EU urban policy reflected prevailing ideas of inter-urban competitiveness, entrepreneurialism, and involvement of the private sector in urban regeneration initiatives, goals generally associated with a neoliberal urban agenda (e.g., Harvey, 1989, 2006). Notwithstanding, EU urban policy blended these goals with concerns over environmental sustainability, conservation of cultural heritage, and economic and social cohesion (European Commission, 1996, 1998, 1999). The policy implicitly suggested that the success of this urban agenda hinged upon more flexible modes of urban governance, including partnerships with the private sector, a streamlined bureaucracy, and cross-scale and cross-sector co-operation. Large-scale urban projects, mega-events, and place-making strategies played a crucial role in bringing about the urban agenda and in experimenting with novel forms of urban governance (Swyngedouw et al., 2002; Moulaert et al., 2003). 
This EU narrative reached the wider Portuguese political scene in 2000 when the Ministry of Environment and Spatial Planning of a newly elected Socialist government appropriated them into its flagship policy - the Polis Program (MAOT, 2000). The program initially targeted the run-down inner-city areas of eighteen medium-sized cities, involving an estimated investment of nearly $€ 1$ billion between 2000 and $2006 .{ }^{8}$ The program rode on the success wave of Lisbon's urban regeneration for the world fair EXPO'98 - a textbook case of neoliberal urbanization in the view of local scholars (Cabral, 2002a; Cabral and Rato, 2003). Praise to the newly renovated public spaces in the EXPO area was such that Polis policymakers promised the program would "take the EXPO to the whole country" (Correia, 2003).

Taking the EXPO elsewhere meant the state would play an interventionist and welfare-oriented role in fixing the 'unplanned' condition of the Portuguese city through the Polis Program (Baptista, 2008, 2012). ${ }^{9}$ In contrast to their European counterparts, policymakers posited, Portuguese cities grew disorganized and lacked the infrastructures and public spaces adequate for contemporary living. As a result, cities bred "marginality, exclusion and poverty." of [Portugal depended] on cities' social stability, environmental standards, beauty and economic efficacy." 11 In their view, it was the central government's role to educate private developers and citizens about a "new way of living the city" (Silva and Correia, 2005).

What the 'new way' meant to policymakers enlightens us about the extent to which they massaged 'neoliberal' ideas available in the EU policy arena into crafting the Polis Program. The 'new way' - in contrast with the 'old' and 'unplanned' way-focused on the quality of open public spaces, the use of ICT, the role of knowledge and recreation in attracting the creative class, and the virtues of intergenerational and multicultural urban living (MAOT, 2000). The 'new' city life would be fit to "break through the frontiers of the new economy that will significantly shape the new millennium."12 Policymakers hoped there would be trickle-down effects resulting from the Polis Program: rehabilitation of private property, new businesses and employment opportunities, and further urban redevelopment would follow suit after the rehabilitation of public space. Policymakers envisaged a renewed urban life for Portuguese cities that placed these in line with the ideals of mainstream EU discourse intuitively associated with 'neoliberal' forms of urbanization. However, because the urban problems confronted by Portuguese policymakers were different from those faced by their European counterparts, the means to fix them also differed.

How the 'new way' of city living was to be achieved departed from the focus on privatization and state intervention to facilitate capitalist accumulation presumed in dominant 'political economy' critiques of neoliberal urbanization. As policymakers put it, the Polis Program intended not to fund urban speculation, but to avoid it. ${ }^{13}$ Policymakers were adamant that the "demonstration effect" of how to rehabilitate public space in the public interest could only be undertaken by public institutions. The involvement of the private sector would "contaminate" such intent. In a direct reference to past wrongdoings of real estate developers, one policymaker stated that "it takes years to undo a misdeed in the territory, so we must keep [the Polis] interventions under a public logic." ${ }^{14}$ Instead of involving the private sector, policymakers proposed that municipal government of each participating city joined the Ministry in a public-public partnership - the Polis Society - to deliver the program locally. Inspired by the EXPO'98 corporate management model, the Polis Societies would operate under a regime of exception that provided them discretionary planning and development powers over the redevelopment area (Baptista, 2013). The partnerships would have a full-time dedicated staff drawn from Parque EXPO 98, the public redevelopment company responsible for delivering the world fair in Lisbon. ${ }^{15}$ Policymakers believed that, if successfully replicated, the EXPO model would overcome the cumbersomeness of planning bureaucracy, stimulate a 
new governance culture within municipalities, and assure the effective delivery of the program by 2006. Policymakers' preference for a more entrepreneurial and discretionary model of program delivery outside of existing state bureaucracies was thus in line with the wider EU inclination toward business-like and more flexible forms of delivering public goods.

However, policymakers' insistence in public-led action begs questioning: how could - and perhaps more importantly, why would - the government of a country deeply inserted in the European economy at the turn of the $20^{\text {th }}$-century go alone at the task of redeveloping public spaces where its wealthier counterparts seemingly would not- - whether for ideological inclination or lack of financial capacity? In fact, one policymaker admitted that this public-driven impetus for rehabilitating cities was taken with great surprise by European counterparts when the Ministry presented the Polis Program at an informal EU environmental summit. ${ }^{16}$ One way to explain policymakers' predilection for a public intervention may relate to the availability of EU aid grants to finance up to $75 \%$ of state-led public works. ${ }^{17}$ The central government and the municipalities could tap into these funds to support Polis projects by matching the remaining funds. This would make it possible to focus on the rehabilitation of public spaces and to preclude the involvement of the private sector in the Program's delivery. Another way to explain it would be to take stock of mainstream views on the historically centralized nature of the Portuguese state apparatus (Cabral, 2002b; Carvalho, 2003; Ruivo, 2000) and to read the Polis Program as a case of the state using its weight to facilitate 'neoliberalization'. With EU funding available with little strings attached to the future use of public infrastructure, Portugal would not be the first (or the last) case of state engagement in promoting the transformation of cities along 'neoliberal' precepts.

Yet, as pointed out earlier, these interpretations seemingly rely too heavily, and perhaps unnecessarily, on 'neoliberalism' as the analytical lens which to filter all aspects of urban development in this case. The contradictions posed by policymakers' focus on a 'new way' of city living that engages with neoliberal imaginations of urban space, while remaining averse to privatization and private sector engagement, should give us pause. If Peck (2004) is right in pointing out that one of the fundamental characteristics of 'neoliberalism' as an economic discourse is to depoliticize state-economy relationships and to naturalize the market as the dominant logics of operation, why is it that Polis policymakers seemingly insisted on a logics of government that remained eminently public and hence political? Neoliberalism, in its 'political economy' variant, may be a relevant concept through which to partly analyze, explain, and criticize what is going on in this Portuguese case. But it might not be the only (or the most) relevant one.

I propose we see the Polis Program alternatively as an interventionist program led by a governing elite committed to developing a welfare state in the ideal terms of its European counterparts at a time when the welfare state (as an ideal and as a practice) was already under great strain. When the attack on the welfare state began in Europe in the 1970s, as 'political economy' critics of neoliberalism would have it, there was little to none welfare state to roll back in Portugal (Santos, 1990; Barreto 1996). It was only after the 1974 revolution and, more consistently, after the 1986 accession to the European Economic Community (later the EU) that Portugal began rolling out a wide program of social services and public infrastructures (ibidem). The creation of the Polis Program in 2000, with its focus on public led-intervention, public space for public use, and disciplining of private developers makes sense in the context of a state apparatus that was still thinking of itself as 'modernizing' towards an 'European' welfare ideal already in decline elsewhere in the EU and the world at large (cf. Baptista, 2012). ${ }^{18}$ With its impetus to extend the benefits of modern city living to a greater number of urban citizens, to fix urban problems, and to use the powers of the state to redistribute social goods and stimulate social cohesion, the Polis Program constitutes an exemplar of state intervention within a welfare logic that seeks to be a corrective to the logics 
of capitalist accumulation. The Polis Program puts the urban at the core of state politics, of normative judgments of what the city should be. Moreover, this interpretation resonates with the governance approach proposed by policymakers to deliver the Polis Program. Fixing the 'unplanned country' meant encouraging a 'new way' of city living and finding new ways of governing the city that overcame the proliferation of public jurisdictions and the challenges of coordinated action within cities, yet remained within the realm of public action with an eye on the public good.

This alternative reading of the Polis Program could perhaps easily map onto the 'governmentality' approach to the study of neoliberalism. In this light, the Polis Program would be described as an attempt of the Portuguese state to consolidate its political reach into the social realm of the urban by deploying (neoliberal) discourses and techniques with results that are not necessarily neoliberal. The 'new way' of living the city advanced by Polis policymakers could perhaps be interpreted as the state's attempt at shaping the conduct of urban dwellers amenable to a 'new' (neoliberal) subjectivity. This 'governmentality' interpretation is of value (in the same measure that the 'political economy' interpretation is) in providing an understanding of the Polis Program as part of an overarching program of rule that arguably dominates the conditions of contemporary urbanization and politics.

Yet, in focusing on such grand narrative of neoliberalism (Collier's 'big Leviathan'), both approaches pre-determine the lines of analytical inquiry and obscure the matters at the heart of urban politics in Portuguese cities. Put differently, if we dare to abandon the dominant approaches in the study of contemporary urbanization that place neoliberalism at the center of inquiry and, instead, mobilize other concepts to play a part in the actual complex dynamics of urban politics (e.g., welfare state), we may be better placed to theorize about what is happening in this Portuguese case.

\section{CRITIQUES OF THE POLIS PROGRAM}

An examination of the critiques of the Polis Program advanced by local actors provides further insights into the different aspects animating urban politics in the Portuguese context. It highlights how the Polis Program became a policy space in which different aspects of the program's governance were debated as broader implicit concerns regarding the country's process of democratization and modernization since the end of the dictatorship in 1974. Some of the most relevant aspects under discussion were the role of different levels of government, the primacy of the rule of the law and due process, and the role of urban planning and technical expertise.

When the Polis Program bill reached the Portuguese Parliament for approval in June 2000 , the program's agenda and its discretionary governance instruments fueled an opposition movement inside and outside Parliament involving MPs, academics-cum-critics, and opinionmakers. The crux of Parliamentary discussions was the role played by the central government in contemporary urban governance, the relationship between levels of government (central and municipal), but not on the merits (or appropriateness) of a public-led intervention. The program prompted critiques by MPs from across the political spectrum - from the Popular Party and Social Democratic Party on the right to the Left Block, the Communist Party, and the Green Party on the left. MPs were particularly incensed by what they perceived to be a centralizing, co-opting, and illegitimate intervention of the central government in municipal affairs. They also debated the justification and legitimacy of the Polis Societies and their regime of exception. Unlike critiques advanced by academics (see below), MPs showed little attention to the nature of the 'good city' promoted by the Program. There was a seeming consensus over the need to intervene in Portuguese cities - even a consensus that 'that' type of urban rehabilitation and environmental improvement was desirable. The core of the 
discussion was how to intervene, not the outcome of the intervention.

The unanimous view among MPs was this: the government led by the Socialist Party was overstepping the boundaries of power distribution between the central government and the municipalities. The overstepping was portrayed as a violent act of domination, exploiting municipalities' weakest link - their thirst for funding. Communist MP Joaquim Matias noted that, without the Polis Program, EU aid grants would be openly available to municipalities. Because the government earmarked substantial amounts of that funding for the program, municipalities had no choice other than to accept partaking in it. He thought that municipalities were forced to accept the Polis Societies and be dispossessed of their planning and land management powers. ${ }^{19}$ Popular Party MP Manuel Queiró concurred with his Communist colleague, arguing that the central government heralded "centralism as the fundamental factor of efficacy and quality of public intervention" while suggesting that municipalities were accessory to land speculation. ${ }^{20}$ Moreover, for MPs on both ends of the political spectrum, this was a question of the need to decentralize state functions to the level at which the public interest would be best served-i.e. to the Municipality. On the right, the Social Democrat MP José Eduardo Martins claimed that it was self-evident that "the improvement of quality of life in cities [was] a competency, prima facie, of cities through their political municipal structures." ${ }^{21}$ On the left, Communist MP Matias joined the choir and claimed that municipalities had served better the public interest than the central government ever had. Municipalities were "the harbingers" of environmental protection and urban rehabilitation, Matias argued, whereas the central government showed a far greater record of mismanagement of the territory. ${ }^{22}$

What is at stake in these discussions is more than arguments about decentralization and subsidiarity in the context of the re-scaling of state spaces that scholars identified elsewhere at the time (e.g. Brenner, 1999, 2004). Amongst Portuguese commentators and political elites, concerns with power devolution to the municipal level have been deeply entwined with a denunciation of the dictatorship period and with the high hopes in the country's process of democratization and modernization (cf. Oliveira, 1996). Hence, it is no coincidence that MPs across the political spectrum defended the same view, even if we take lightly the political rhetoric imbued in parliamentary discussions. At the heart of the process of reforming, modernizing, and democratizing the "labyrinth-like" Portuguese state apparatus (Ruivo, 2000) is the aspiration of progress towards an idealized 'European' (and efficient) state apparatus - i.e. one in which each level of government has its responsibilities formally assigned and respected, in which public action is taken at the scale that better serves the public interest.

This view of the role of the state was further scrutinized when MPs adamantly rejected the idea of using a regime of exception to deliver the Program. Their interjections revealed a sense of respect for the universal mandate of the law and an understanding that exceptions can be mobilized with personalized discretion, to promote private or partisan interests, not the public interest, as they usually are in the 'labyrinth-state'. Even if the exceptional measures were to be deployed to improve the efficiency and effectiveness of the bureaucracy, as the central government claimed, then the overarching procedures of bureaucratic operation should be changed instead of "enshrining the exception as a rule," as noted by MP Martins. ${ }^{23}$

Communist MP Matias shared his view, positing that if any legal overhaul was to take place, then it should reinforce the role of municipalities, not the power of the central bureaucracy: "if there is something to be simplified it is certainly at the level of the central administration's [cumbersome] response mechanisms to municipal proposals; if something is worthy of an exception treatment, so be it that [we] legislate for the exception to reinforce the existing competences held by [municipalities]." 24

Ultimately the discussion was one of legitimacy to intervene in urban transformation 
at the city level. The overarching view was that legitimate public action rested on those elected locally, i.e. in the Municipality, with the consent and scrutiny of local citizens. Hence, the proposal to create a regime of exception that transferred municipal responsibilities to the Polis Societies was unacceptable. Left Block MP Luís Fazenda doubted that municipalities would have any democratic control of decisions under the Polis Societies. ${ }^{25}$ Social Democrat MP Martins believed that entrusting urban transformations to an "anonymous and nonelected" body, such as the Polis Society, was perilous. ${ }^{26}$ Communist MP Matias concurred: "Nothing advises us to remove these competences from democratically elected institutions, [which are] subject to the principles of equality, proportionality, justice, impartiality and transparency; especially if what is at stake is the [power] to contract out... [one billion Euros] in [land] acquisitions and construction [projects]." ${ }^{27}$ The way in which Matias populates his speech with buzzwords such as 'impartiality' and 'transparency' is a good illustration of the formal concerns that drive urban politics in the Portuguese context.

MPs paid little attention to the nature of the 'good city' envisaged by the Polis Program. Such critiques emerged mostly among academics, especially architects and a few planners, who often play the role of public intellectuals and expert critics in the Portuguese context. Opposition to the Polis Program was inextricably linked to ongoing critiques of its predecessor, the EXPO 98, which scholars framed in the context of entrepreneurial forms of intra-urban competition at the European and international scale, while noting the uneven development that was due to happen (Ferreira, 1997; Ferreira and Indovina, 1999). These critiques tended to be entangled more with an architectural discourse of urban aesthetics and a perception of the urban condition of the Portuguese city than with the impacts of models of urbanization that could be deemed 'neoliberal'. Moreover, the discussion also focused on the role of the state in redistributing social goods in a way that contributed to the modernization of the country (Ferreira and Indovina, 1999). ${ }^{28}$

For instance, João Cabral, an architect by training and a university professor of architecture and planning, claimed that both the EXPO and the Polis Program were "examples of the most recent tendencies for the affirmation of a new urban policy in the context of a broader policy of economic restructuring and reformulation of the role of the State [sic]" (Cabral, 2002a, p. 27). He was particularly concerned with the role the state would play in creating surplus value to private landlords in the areas where improvements of public spaces were to take place. He concluded that, in this context, the challenge was whether emerging strategies to improve the productive and competitive capacities of cities could strike an adequate balance between capital accumulation and social cohesion (cf. Cabral and Rato, 2003).

Cabral's concerns regarding the political economy of urban restructuring had little echo among his peers. ${ }^{29}$ Architects and planners voiced concerns regarding the ideas of the 'good city' advanced by the Polis Program that reflected local concerns about the role of architecture, planning, and expert knowledge in shaping urban sustainability and improved conditions of urban livelihood. Jorge Figueira, an architect and a critic of architectural design, thought the program focused on relevant aspects of urban livelihood, but tended to lie somewhere "between the ecological and the posh-pretentious" (Figueira, 2003, p. 97). He thought the program entailed "a belated attempt at "hygienizing" the Portuguese urban condition (Figueira, 2003, p. 98), that emerged "more from a short-sighted and populist logic than from an analysis of the real problems of [Portuguese] cities" (Figueira, 2003, p. 96). Another professor of architecture, Nuno Grande, criticized the Program's focus on public spaces of inner-city areas and historic centers and its predilection for high design and symbolic interventions. He felt this was less of a priority than intervening in urban peripheries and suburbs, where most of the last four decades of urban development had unfolded with adverse consequences (Grande, 2003). Fernando Nunes da Silva, a civil engineer and 
professor of planning and transportation, offered a pun that equated the name of the program, Polis, with the word 'polish' (Silva, 2003), thus anticipating the Program would end up as a large-scale operation of city embellishment. Nunes da Silva thought the program would undoubtedly have positive impacts, if only because some cities would see through solutions to "urban and environmental problems ongoing for decades" (Silva, 2003, p. 27). He urged policymakers to formulate a "real policy for the cities" that reserved for the state a typical welfare role: "[a policy] based on a critical analysis of the existing urban network, with a long term view, in coordination with [plans for] large infrastructure projects and the provision of facilities for [public] collective use, which [will] promote the use of new technologies and the access to material and cultural consumption goods in medium-sized cities" (ibidem).

Despite all the specificities of the analyses and the comprehensiveness of solutions foregrounded, what comes across in the views of these academics-cum-critics is how they placed the Polis Program squarely within contemporary discussions of urban sustainability playing out at a European (or even global) level. Much like the aspirations showed by Polis policymakers in creating a new, more modern and cosmopolitan way of urban living, these critics also aspired to overcome the complex problems of Portuguese cities through the good use of architecture, planning, and expertise. There seemed to be no disagreement that Portuguese cities needed to be intervened upon, or that the state had a major and active role to play in it. But fears that the Program would promote inequality, social polarization, or uneven private accumulation - effects commonsensically associated with neoliberalism, especially in its 'political economy' variant — were to take the backseat to those of urban sustainability, modernization, and democratization.

\section{CONCLUSION: WHY CALL IT 'NEOLIBERAL'?}

Healey (2012) recently noted that attention to the circulation of concepts could enhance our sensibility to how they come to dominate the localities they land on. In referring to planning, she cautioned against conceiving it as "a thing-like object or an actor-like object" with a "recognizable form and materiality" (Healey, 2012, p. 202). Instead, Healey suggested we investigate how planning is "an evolving, fluid, mental concept, constructed from the meanings given to it in all kinds of specific locales and the encounters and tensions between these" (ibidem).

Drawing a parallel with Healey's discussion on the travels of planning as a concept, this article started from a similar premise about scholarly critiques and analytical frameworks of neoliberalism in urban studies: they also have an intellectual place of origin, which has been formed on particular urban experiences; they also travel elsewhere and acquire complex meaning; they too may come to exert a form of hegemonic power that can prevent other concepts, analytical frameworks, and forms of critique to play a role in their own right; and, as a result, they may overlook, at best, or even distort, the understanding of local conditions. As documented earlier in the article, other scholars have already raised concerns about the 'travels' of critiques of neoliberalism, both in terms of how the concept is handled and in terms of two particular meta-analytical aspects: the status and the sites of epistemological production of neoliberalism. The concern here is the possibility of foreclosing alternative readings of contemporary urban transformations and politics if we maintain the hegemonic status of neoliberalism when studying cities beyond its sites of epistemological production (as a theoretical concept and an analytical framework).

Using the analysis of the formation of a Portuguese urban regeneration program initiated in 2000, this article took up and expanded on these meta-analytical discussions by 
noting how neoliberalism, as a theoretical concept, provides partial explanations for the precise shape or the local critique of the Polis Program. Through an analysis of the program's formation and of critiques waged against it, the article illustrated how theorizing the Portuguese urban condition required recourse to ideas of democratization, modernization, and of the welfare state alongside the concept of neoliberalism. In order to further open up for discussion the overinvestment in neoliberalism in contemporary urban studies, the article teased out some of the effects of using neoliberalism as the primary analytical framework to study of the Polis Program. For instance, by starting from the viewpoint of neoliberalism, we would probably be tempted to focus our attention on the changing relationship between the central and local levels of government imposed by the Polis Program and to read these as a matter of restructuring of state spaces for the sake of urban competitiveness. Or, we may also be tempted to focus our attention on the program's 'new way' of living the city as an attempt to shape the conduct of urban dwellers amenable to a 'new' (neoliberal) subjectivity. Or, even, we could be tempted to understand the critiques waged by academics regarding the role of architecture and planning as the (neoliberal) de-politicization of the urban condition as a strict technical matter. Even though all these readings are possible and useful, they also overlook, marginalize, or dismiss the matters at the heart of local politics: how local elites strived for an idealized 'European' welfare (and efficient) state apparatus, how they defended decentralization and devolution as a matter of democratization and modernization, or how they endeavored for urban sustainability where livelihood conditions were the more critical.

Looking at the formation of the Polis Program and the critiques waged against it provides a valuable angle into how the program was discursively produced, how its constitution drew on ideas from elsewhere, and the politics of representing policy purposes, objects of intervention and methods of action. Certainly, following Healey above, many of these representational and discursive elements ended up acquiring a refined or even different meaning and substantive relevance throughout the program's implementation phase. Potentially, different (or even new) concepts may rise to prominence at different moments of the program's implementation process, for instance, as a result of state budget cuts in place since 2002-2003 or due to local contestation and party politics in each of the 39 cities participating in the program. Irrespective of these potential transformations, the moment of policy formation remains a suitable window into exploring the implicit referents that drive change in cities and how they come to be constituted in relation to each other and in response to localized situations. In other words, scrutinizing the formation of the Polis Program to illustrate a meta-analytical point draws our attention to the space of constitutive relationality of different concepts proposed here as a possible corrective against the hegemonic methodological commitment - the essentializing and universalizing — of neoliberalism that we find in contemporary urban studies literature (see also Ward, 2010).

As noted earlier, a 'political economy' approach to the study and critique of contemporary urbanization and urban politics places perhaps too much attention on the macro-structural dynamics of the capitalist city in relation to a purported widespread of neoliberalism (cf. Brenner, 2009; Roy, 2011). However, as Ferguson (2009) lamented, much of the recent critical scholarship developed in this light has offered unsurprising insights, perhaps as a result of what Parnell and Robinson (2012, p. 594) termed its "ready-made interpretive framework." This is not because a 'political economy' investigation of contemporary cities has little to offer about the urban condition the world over, quite to the contrary. But perhaps because, in 'traveling' to places outside of its sites of epistemological production (the capitalist core), it can retain explanatory power only if it grows larger and more abstract, thus loosing sight of the politics of each place (cf. Collier, 2012). The corrective may not lie in shifting our analytical attention to a 'governmentality' line of inquiry either. The poststructuralist approach to the study of neoliberalism and the city, while useful 
in detailing the microanalysis of everyday acts of resistance, retains neoliberalism as the pregiven concept through which the urban condition is theorized and analyzed.

The cost of this overinvestment in neoliberalism may be that, in theorizing contemporary urban conditions in places we know less about - the cities in the 'borderlands' of urban theory, such as those in Portugal-we will have limited insights to offer about the historically contingent drivers of urban politics and urban transformations. Certainly 'political economy' analyses have asked us to pay attention to the "geographies of 'actually existing neoliberalism"” (Brenner and Theodore, 2002a). But if being 'neoliberal' can come in such a wide variety of shapes and forms, and if it accommodates in myriad ways existing institutional histories and practices, will there be any space left for other things to make a difference in the outcomes of urban politics and to acquire explanatory relevance?

Some scholars are beginning to provide space to theorize concepts other than neoliberalism or to theorize it differently. For instance, Parnell and Pieterse (2010) pay attention to notion of rights to the city in post-Apartheid South Africa. Focusing on the same urban context, Parnell and Robinson (2012) explore the relevance of theorizing further the agency of local government in the context of a developmental state and entrenched urban poverty. This article aligns with the work of these authors in arguing that, in spite of a focus on ideas of urban entrepreneurialism and urban competitiveness usually deemed 'neoliberal', what lay at the core of the Polis Program was an attempt at expanding the reach of the state to an idealized welfare model. Others are seeking to broaden the analytical toolkit to focus on urban assemblages and recent developments in Actor-Network Theory (e.g., Farías and Bender, 2010; McFarlane, 2011). Arguing that "[t]echniques have no necessary loyalty to the political program within which they were developed" (Ferguson, 2011, p. 66), Ferguson provocatively suggests that 'neoliberal' ideas may be appropriated for progressive forms of government. Urban studies has much to gain from this ongoing questioning and theoretical experimentation, even though, as Parnell and Robinson (2012, p. 593) put it, the recalibration of theory production, "while not necessarily comfortable for those in established positions of intellectual power, is desirable and maybe even overdue." 


\section{NOTES}

1 Research on the Portuguese case study was conducted with the support of a Doctoral Fellowship from Fundação para a Ciência e a Tecnologia, Portugal, under European Union's POCI 2010 and FSE. This article was written during the author's time with the Oxford Programme for the Future of Cities as the Sir Nigel Mobbs Research Fellow. For their comments on different versions of this article, the author would like to thank the contributions of the journal's Editor and the reviewers, Tiago Castela, Stephanie Clare, Amy Hinterberger, Catherine Montgomery, Natalie Porter, Steve Rayner, and Gisa Weszkalnys. 2 Correspondence concerning this article should be addressed to Idalina Baptista, Oxford Programme for the Future of Cities, Institute for Science, Innovation and Society, School of Anthropology and Museum Ethnography, University of Oxford, 64 Banbury Road, Oxford OX2 6PN, United Kingdom; telephone: 44 (0) 186-528-8721; fax: 44 (0) 186-5288959; e-mail: idalina.baptista@insis.ox.ac.uk.

3 I distinguish here between 'neoliberalism' as a theoretical concept and 'neoliberalism' as an analytical framework to signal the way the term is treated differently in the literature. When used as a theoretical concept, neoliberalism consists of an abstraction that seeks to explain observed 'real world' referents. When used as an analytical framework, neoliberalism consists of a strategy of inquiry to study, interpret and give meaning to 'real world' phenomena. The distinction is fuzzy and not always clear in the literature.

Others have discussed at length the various ways in which 'neoliberalism' as a concept has been treated in the literature (cf. Clarke, 2008; Ferguson, 2009; Bakker, 2010; Robinson, 2011). In this article, I want to focus on the critiques of the use of 'neoliberalism' as a theoretical concept and an analytical framework.

5 I am aware that categorizing the literature on neoliberalism under the very broad banners of 'political economy' and 'governmentality' constitutes an oversimplification of a rich and complex field and that authors of different persuasions would dispute being grouped under any of them, even if only loosely. The simplification is retained here for textual fluidity. 6 In fact, note how recent literature has begun to use the qualifier 'Anglophone' to refer to the origins of Euro-American urban theory.

7 This is largely based on elite interviews and analysis of official documents about the formation of the Polis Program (cf. Baptista, 2009).

$8 \quad$ Funding for the Polis Program was initially estimated at $€ 800$ million and later updated to $€ 1$ billion (initial values in former Portuguese currency). After negotiations in Parliament and a second round of open applications, the program was extended to a total of 39 cities. The program encountered implementation problems through time. By the end of 2006, the expected date of the Program's conclusion, only 11 of the 39 cities had concluded their Polis projects.

$9 \quad$ As I have argued elsewhere (Baptista 2012), scholars, policymakers and opinionmakers often single out the arguably disorderly nature of urban growth in the country, when compared to other Euro-American cities. I have argued that this narrative has powerfully shaped urban policy in Portugal not so much for its accuracy but because it provides a selective view of the problems of Portuguese cities and how to tackle them (ibidem).

10 Diário da Assembleia da República Série I [Diary of the Assembly of the Republic

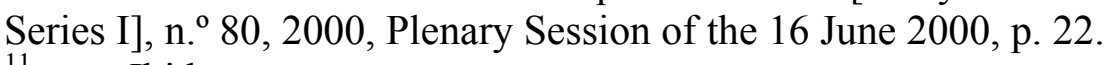

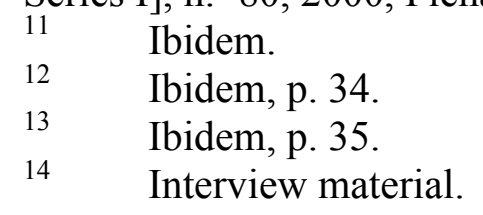


Only 22 of the 39 cities were to have a Polis Society. Only 10 of the Polis Societies were staffed by Parque EXPO.

16 Interview material.

17 Under the EU's redistributive policy, Portugal (and other so-called cohesion

countries) had negotiated a package of EU financial assistance for the period of 2000-2006 to support up to $75 \%$ of the cost of public investments. The financial engineering of the Polis Program accounted for an average of $58 \%$ in EU funding ( $€ 460$ million), $32 \%$ in central and local government funding ( $€ 130$ million each), and $10 \%$ in funding generated from selling developed land (€80 million) (MAOT, 2000, p. 47).

18 Barreto (1996) takes notice of the difficulty of rolling out the welfare state in Portugal at a time when other European countries were starting to reform it. It could be argued that the roll back of the Portuguese welfare state became obvious only after 2011 as a result of the Eurozone crisis.

19 Diário da Assembleia da República Série I [Diary of the Assembly of the Republic Series I], n. ${ }^{\circ} 80$, Plenary Session of 16 June 2000, p. 26.

$20 \quad$ Ibidem, p. 36.

21 Ibidem, p. 30.

$22 \quad$ Ibidem, p. 31.

23 Ibidem, p. 31.

24 Ibidem, p. 32.

25 Ibidem, p. 26-27.

$26 \quad$ Ibidem, p. 31.

27 Ibidem, p. 32.

$28 \quad$ Ferreira and Indovina's edited book was the most thorough study of EXPO 98 published at the time. The volume resulted from an observatory set up by the authors to follow up the EXPO 98 project throughout its implementation.

29 One exception was Helena Roseta, an architect and Socialist MP at the time. Roseta was a dissenting voice against the urban policies promoted by her party's government. She proposed that the central government should implement mechanisms to re-appropriate the benefits of public investment from the private sector (MP Petition to the Portuguese Government, Requerimento n. ${ }^{\circ}$ 1170/VIII/1(AC), 3 May 2000). 


\section{REFERENCES}

Bakker, K., 2005, Neoliberalizing nature? Market environmentalism in water supply in England and Wales. Annals of the Association of American Geographers, Vol. 95, 542-565.

Bakker, K., 2010, The limits of 'neoliberal natures': Debating green neoliberalism. Progress in Human Geography, Vol. 34, 715-735.

Baptista, I., 2008, O Programa POLIS e o "País Desordenado": percepções sobre governância e planeamento urbano em Portugal [POLIS Program and the 'Unplanned Country:' perceptions on governance and urban planning in Portugal]. In M.V. Cabral, T. Saraiva and F.C.D. Silva, editors, Cidade e Cidadania: Governança Urbana e Participação Cidadã em Perspectiva Comparada [City and Citizenship: Urban Governance and Citizen Participation in a Comparative Perspective]. Lisboa, Portugal: Imprensa de Ciências Sociais, 131-176.

Baptista, I., 2009, Regimes of Exception in Urban Planning and Governance: The Case of the Polis Program, Portugal. Unpublished PhD dissertation, Department of City and Regional Planning, University of California, Berkeley.

Baptista, I., 2012, How Portugal became an 'unplanned country': A critique of scholarship on Portuguese urban development and planning. International Journal of Urban and Regional Research, Vol. 36, 1076-1092.

Baptista, I., 2013, Practices of exception in urban governance: Reconfiguring power inside the state. Urban Studies, Vol. 50, 37-52.

Barnett, C., 2005, The consolations of 'neoliberalism'. Geoforum, Vol. 36, 7-12.

Barnett, C., Clarke, N., Cloke, P. and Malpass, A., 2008, The elusive subjects of neoliberalism: Beyond the analytics of governmentality. Cultural Studies, Vol. 22, 624-653.

Barreto, A., editor, 1996, Situação Social em Portugal, 1960-1995 [Social Situation in Portugal, 1960-1995]. Lisboa, Portugal: Imprensa de Ciências Sociais.

Boudreau, J.-A., Kiel, R. and Young, D., 2009, Changing Toronto: Governing Urban Neoliberalism. Toronto, Canada: University of Toronto Press.

Brenner, N., 1999, Globalisation as reterritorialisation: The re-scaling of urban governance in the European Union. Urban Studies, Vol. 36, 431-451.

Brenner, N., 2004, New State Spaces: Urban Governance and the Rescaling of Statehood. Oxford, UK: Oxford University Press.

Brenner, N., 2009, What is critical urban theory? City, Vol. 13, 198-207.

Brenner, N. and Theodore, N., 2002a, Cities and the geographies of "actually existing neoliberalism." Antipode, Vol. 34, 349-379.

Brenner, N. and Theodore, N., editors, 2002b, Spaces of Neoliberalism: Urban Restructuring 
in North America and Western Europe. Oxford, UK: Blackwell.

Brenner, N., Marcuse, P. and Mayer, M., editors, 2012, Cities for People, Not for Profit: Critical Urban Theory and the Right to the City. London, UK: Routledge.

Brenner, N., Peck, J. and Theodore, N., 2010, Variegated neoliberalization: Geographies, modalities, pathways. Global Networks, Vol. 10, 182-222.

Cabral, J., 2002a, Para uma política de cidades: Os imperativos, as novas políticas urbanas, as questões críticas [For a policy for cities: The imperatives, the new urban policies, the critical questions]. Sociedade e Território, Vol. 33, 24-35.

Cabral, J. and Rato, B., 2003, Urban development for competitiveness and cohesion: The Expo 98 urban project in Lisbon. In F. Moulaert, A. Rodriguez and E. Swyngedouw, editors, The Globalized City: Economic Restructuring and Social Polarization in European Cities. Oxford, UK: Oxford University Press, 209-228.

Cabral, M.V., 2002b, Autoritarismo de estado e sociedade civil real em Portugal—Uma pesquisa em curso [State authoritarianism and real civil society in Portugal-An ongoing research]. Encontro FLAD "A Cultura da Responsabilidade" [FLAD Meeting "The Culture of Responsibility”] Lisboa, Portugal: Fundação Luso-Americana para o Desenvolvimento.

Cardoso, A. S., 1988, A modernização e a mudança no território: Tendências e contradições [Modernization and territorial change: Tendencies and contradictions]. In A. C. Gonçalves, A. T. Fernandes and C. L. d'Epinay, editors, La Sociologie et las Nouveaux Défis de la Modernisation [Sociology and the New Challenges of Modernization]. Porto, Portugal: Faculdade de Letras, Universidade do Porto, 269-286.

Carvalho, J.D., 2003, Ordenar a Cidade [Ordering the City]. Coimbra, Portugal: Quarteto Editora.

Castree, N., 2008a, Neoliberalising nature: The logics of deregulation and reregulation. Environment and Planning A, Vol. 40, 131-152.

Castree, N., 2008b, Neoliberalising nature: Processes, effects, and evaluations. Environment and Planning A, Vol. 40, 153-173.

Clarke, J., 2008, Living with/in and without neo-liberalism. Focaal-European Journal of Anthropology, Vol. 51, 135-147.

Collier, S.J., 2011, Post-Soviet Social: Neoliberalism, Social Modernity, Biopolitics. Princeton, NJ: Princeton University Press.

Collier, S.J., 2012, Neoliberalism as big Leviathan, or...? A response to Wacquant and Hilgers. Social Anthropology, Vol. 20, 186-195.

Correia, F.N., 2003, Levar a Expo ao país todo [Take the EXPO to the whole country], an interview with Francisco Nunes Correia by Manuel Graça Dias and Ana Vaz Milheiro. Jornal Arquitectos, Vol. 209, 9-17. 
Dean, M., 1999, Governmentality: Power and Rule in Modern Society. Thousand Oaks, CA: Sage Publications.

European Commission, 1996, European Sustainable Cities-Report by the Expert Group on the Urban Environment to the European Commission. Brussels, Belgium: European Commission.

European Commission, 1998, Sustainable Urban Development in the European Union: A Framework for Action. Brussels, Belgium: European Commission.

European Commission, 1999, ESDP_European Spatial Development Perspective: Towards a Balanced and Sustainable Development of the Territory of the European Union. Brussels, Belgium: European Commission.

Farías, I. and Bender, T., editors, 2010, Urban Assemblages: How Actor-Network Theory Changes Urban Studies. London, UK: Routledge.

Ferguson, J., 2009, The uses of neoliberalism. Antipode, Vol. 41, 166-184.

Ferguson, J., 2011, Toward a left art of government: From 'Foucauldian critique' to Foucauldian politics. History of the Human Sciences, Vol. 24, 61-68.

Ferguson, J., and Gupta, A., 2002, Spatializing states: Toward an ethnography of neoliberal governmentality. American Ethnologist, Vol. 29, 981-1002.

Ferreira, V.M., 1997, A Expo'98 e a metrópole de Lisboa [The Expo'98 and the Lisbon metropolis]. Sociologia-Problemas e Práticas, Vol. 24, 189-195.

Ferreira, V.M., and Indovina, F., editors, 1999, A Cidade da EXPO'98: Uma Reconversão na Frente Ribeirinha de Lisboa? [The City of EXPO'98: A Reconversion in the Riverfront of Lisbon?] Lisboa, Portugal: Editorial Bizâncio.

Figueira, J., 2003, A ordem das dunas nunca será uma política urbana [The ordering of the dunes will never be an urban policy]. Jornal Arquitectos, Vol. 209, 95-98.

Grande, N., 2003, Minho, urbanidade de obra grave [Minho, urbanity of obra grave]. Jornal Arquitectos, Vol. 209, 89-94.

Harvey, D., 1989, From managerialism to entrepreneurialism: The transformation in urban governance in late capitalism. Geografiska Annaler. Series B, Human Geography, Vol. 71, $3-17$.

Harvey, D., 2001, Globalization and the "spatial fix". Geographische Revue: Zeitschrift für Literatur und Diskussion, Vol. 3, 23-30.

Harvey, D., 2005, A Brief History of Neoliberalism. New York, NY: Oxford University Press.

Harvey, D., 2006, Spaces of Global Capitalism: Towards a Theory of Uneven Geographical Development. London, UK: Verso. 
Healey, P., 2012, The universal and the contingent: Some reflections on the transnational flow of planning ideas and practices. Planning Theory, Vol. 11, 188-207.

Healey, P. and Upton, R., 2010, Crossing Borders: International Exchange and Planning Practices. London, UK: Routledge.

Jacobs, J. M., 2012, Commentary-Comparing comparative urbanisms. Urban Geography, Vol. 33, 904-914.

Jones, M. and Ward, K., 2002, Excavating the logic of British urban policy: Neoliberalism as the "crisis of crisis-management." Antipode, Vol. 34, 473-494.

Larner, W., 2003, Neoliberalism? Environment and Planning D, Vol. 21, 509-512.

Leitner, H., Peck, J. and Sheppard, E.S., 2007, Contesting Neoliberalism: Urban Frontiers. New York, NY: The Guilford Press.

MAOT, 2000, Programa Polis, Programa de Requalificação Urbana e Valorização Ambiental de Cidades [Polis Program, Program for Urban Rehabilitation and Environmental Improvement of Cities]. Lisboa, Portugal: Ministério do Ambiente e do Ordenamento do Território.

Marques, T. S., 2004, Portugal na Transição do Século: Retratos e Dinâmicas Territoriais [Portugal at the Transition of the Century: Portraits and Territorial Dynamics]. Porto, Portugal: Edições Afrontamento.

McFarlane, C. and Robinson, J., 2012, Introduction-Experiments in comparative urbanism. Urban Geography, Vol. 33, 765-773.

McFarlane, C., 2010, The comparative city: Knowledge, learning, urbanism. International Journal of Urban and Regional Research, Vol. 34, 725-742.

McFarlane, C., 2011, Assemblage and critical urbanism. City, Vol. 15, 204-224.

Miller, P. and Rose, N., 2008, Governing the Present: Administering Economic, Social and Personal Life. Malden, MA: Polity Press.

Mitchell, K., 2004, Crossing the Neoliberal Line: Pacific Rim Migration and the Metropolis. Philadelphia, PA: Temple University Press.

Moulaert, F., Rodríguez, A. and Swyngedouw, E., editors, 2003, The Globalized City: Economic Restructuring and Social Polarization in European Cities. Oxford, UK: Oxford University Press.

Nijman, J., 2007, Place-particularity and "deep analogies": A comparative essay on Miami's rise as a world city. Urban Geography, Vol. 28, 92-107.

Oliveira, C., editor, 1996, História dos Municípios e do Poder Local (dos Finais da Idade Média à União Europeia) [The History of Municipalities and Local Power (from the End of the Middle Ages to the European Union)]. Lisboa, Portugal: Círculo de Leitores. 
Ong, A., 2006, Neoliberalism as Exception: Mutations in Citizenship and Sovereignty. Durham, NC: Duke University Press.

Parnell, S. and Pieterse, E., 2010, The 'right to the city': Institutional imperatives of a developmental state. International Journal of Urban and Regional Research, Vol. 34, 146162.

Parnell, S. and Robinson, J., 2012, (Re)theorizing cities from the global South: Looking beyond neoliberalism. Urban Geography, Vol. 33, 593-617.

Peck, J., 2004, Geography and public policy: Constructions of neoliberalism. Progress in Human Geography, Vol. 28, 392-405.

Peck, J. and Tickell, A., 2002, Neoliberalizing space. Antipode, Vol. 34, 380-404.

Peck, J., Theodore, N. and Brenner, N., 2009, Neoliberal urbanism: Models, moments, mutations. The SAIS Review of International Affairs, Vol. XXIX, 49-66.

Portas, N., Domingues, Á. and Cabral, J., 2003, Políticas Urbanas: Tendências, Estratégias e Oportunidades [Urban Policies: Tendencies, Strategies, and Opportunities]. Lisboa, Portugal: Fundação Calouste Gulbenkian.

Robinson, J., 2002, Global and world cities: A view from off the map. International Journal of Urban and Regional Research, Vol. 26, 531-554.

Robinson, J., 2006, Ordinary Cities: Between Modernity and Development. London, UK: Routledge.

Robinson, J., 2010, Cities in a world of cities: The comparative gesture, International Journal of Urban and Regional Research, Vol. 35, 1-23.

Robinson, J., 2011, 2010 Urban Geography Plenary Lecture-The travels of urban neoliberalism: Taking stock of the internationalization of urban theory. Urban Geography, Vol. 32, 1087-1109.

Roy, A., 2009, The 21st-century metropolis: New geographies of theory. Regional Studies, Vol. 43, 819-830.

Roy, A., 2011, Urbanisms, worlding practices and the theory of planning. Planning Theory, Vol. 10, 6-15.

Roy, A. and Ong, A., editors, 2011, Worlding Cities: Asian Experiments and the Art of Being Global. Oxford, UK: Wiley-Blackwell.

Ruivo, F., 2000, O Estado Labiríntico: o Poder Relacional entre Poderes Local e Central em Portugal [The Labyrinth State: the Relational Power between the Local and Central Powers in Portugal]. Porto, Portugal: Edições Afrontamento.

Salgueiro, T. B., 1992, A Cidade em Portugal: Uma Geografia Urbana [The City in 
Portugal: An Urban Geography]. Porto, Portugal: Edições Afrontamento.

Sandercock, L., 1995, Voices from the borderlands: A meditation on a metaphor. Journal of Planning Education and Research, Vol. 14, 77-88.

Santos, B.de S., 1990, O Estado e a Sociedade em Portugal (1974-1988) [The State and Society in Portugal (1974-1988)]. Porto, Portugal: Edições Afrontamento.

Sedgwick, E., 2003, Touching Feeling: Affect, Pedagogy, Performativity. Durham, NC: Duke University Press.

Silva, C. N., 1994, Política Urbana em Lisboa, 1926-1974 [Urban Policy in Lisbon, 19261974]. Lisboa, Portugal: Livros Horizonte.

Silva, F.N.D., 2003, O Programa Polis: Da escala 1/10.000 à 1/1 [The Polis Program: From scale 1/10,000 to 1/1]. Jornal Arquitectos, Vol. 209, 21-27.

Silva, M.M.D. and Correia, F.N., 2005, Uma nova forma de viver as cidades: O exemplo demonstrativo do Programa Polis [A new way of living the cities: The demonstration example of the Polis Program]. Sociedade e Território, Vol. 39, 32-43.

Smith, N., 1996, The New Urban Frontier: Gentrification and the Revanchist City. London, UK: Routledge.

Smith, N., 2002, New globalism, new urbanism: Gentrification as global urban strategy. Antipode, Vol. 34, 427-450.

Swyngedouw, E., Moulaert, F. and Rodriguez, A., 2002, Neoliberal urbanization in Europe: Large-scale urban development projects and the new urban policy. Antipode, Vol. 34, 542577.

Ward, K., 2010, Towards a relational comparative approach to the study of cities. Progress in Human Geography, Vol. 34, 471-487.

Watson, V., 2009, Seeing from the South: Refocusing urban planning on the globe's central urban issues. Urban Studies, Vol. 46, 2259-2275.

Weber, R., 2002, Extracting value from the city: Neoliberalism and urban redevelopment. Antipode, Vol. 34, 519-540. 